\title{
EVALUASI PERBANDINGAN PERFORMA JARINGAN WIRELESS SENSOR NETWORK DALAM SERANGAN SYBIL ATTACK DAN HELLO FLOOD ATTACK
}

\section{TUGAS AKHIR}

Sebagai Persyaratan Guna Meraih Gelar Sarjana Strata 1

Teknik Informatika Universitas Muhammadiyah Malang

Hawwin Purnama Akbar 201310370311216

JURUSAN TEKNIK INFORMATIKA FAKULTAS TEKNIK UNIVERSITAS MUHAMMADIYAH MALANG 2017 


\section{LEMBAR PERSETUJUAN}

\section{EVALUASI PERBANDINGAN PERFORMA JARINGAN \\ WIRELESS SENSOR NETWORK DALAM SERANGAN SYBIL ATTACK DAN HELLO FLOOD ATTACK}

\section{TUGAS AKHIR}

Diajukan Untuk Memenuhi

Persyaratan Guna Meraih Gelar Sarjana Strata 1

Teknik Informatika Universitas Muhammadiyah Malang

Pembimbing I

Diah Risqiwati, S.T., M.T.

NIP. 108.1410.0545
- Pembimbing II

Menyetujui, 


\section{LEMBAR PENGESAHAN}

\section{EVALUASI PERBANDINGAN PERFORMA JARINGAN WIRELESS SENSOR NETWORK DALAM SERANGAN SYBIL ATTACK DAN HELLO FLOOD ATTACK}

\section{TUGAS AKHIR}

Diajukan Untuk Memenuhi

Persyaratan Guna Meraih Gelar Sarjana Strata 1

Teknik Informatika Universitas Muhammadiyah Malang

Disusun oleh :

Hawwin Purnama Akbar

201310370311216

Tugas Akhir ini telah diuji dan dinyatakan lulus melalui sidang majelis penguji Pada :

Menyetujui,

Penguji I Penguji II

Ali Sofyan Kholimi, M. Kom.

Zamah Sari, M.T.

NIP. 102.1410.0562

NIDN. 108.1410.0555

Mengetahui,

Ketua Jurusan Informatika

Yuda Munarko, S. Kom, M.Sc

NIDN: 10806110443 


\section{LEMBAR PERNYATAAN}

Yang bertanda tangan dibawah ini :

NAMA

NIM

FAK./JUR.

\section{: Hawwin Purnama Akbar}

: 201310370311216

\section{: TEKNIK/INFORMATIKA}

Dengan ini saya menyatakan bahwa Tugas Akhir dengan judul "EVALUASI PERBANDINGAN PERFORMA JARINGAN WIRELESS SENSOR NETWORK DALAM SERANGAN SYBIL ATTACK DAN HELLO FLOOD ATTACK" beserta seluruh isinya adalah karya saya sendiri dan bukan merupakan karya tulis orang lain, baik sebagian maupun seluruhnya, kecuali dalam bentuk kutipan yang telah disebutkan sumbernya.

Demikian surat pernyataan ini saya buat dengan sebenar-benarnya. Apabila kemudian ditemukan adanya pelanggaran terhadap etika keilmuan dalam karya saya ini, atau ada klaim dari pihak lain terhadap keaslian karya saya ini maka saya siap menanggung segala bentuk resiko/sanksi yang berlaku.

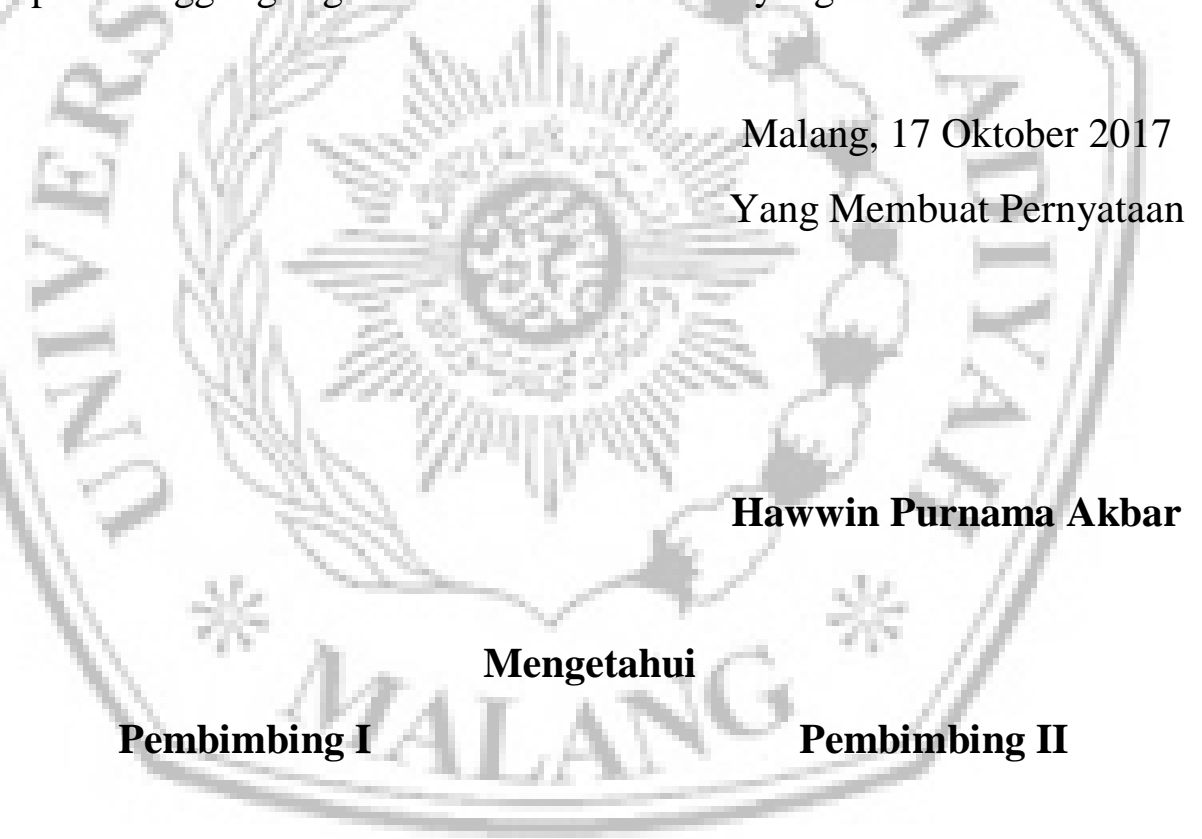

Diah Risqiwati,S.T., M. T.

Denar Regata A S.Kom., M.Kom.

NIP. 108.1410.0545

NIDN. 108.1612.0591 


\begin{abstract}
ABSTRAK
Perkembangan ilmu pengetahuan pada bidang teknologi jaringan terjadi sangat cepat karena mengikuti perkembangan kebutuhan manusia. Salah satu teknologi jaringan yang saat ini menarik perhatian masyarakat adalah teknologi Wireless Sensor Network(WSN). WSN adalah jaringan dari kumpulan sensor yang terhubung menggunakan teknologi wireless secara ad-hoc dan setiap sensor node digunakan untuk proses pengumpulan data dan menghubungkan dengan node yang lain melalui jaringan wireless. Karena pada kebanyakan kasus aplikasi WSN digunakan pada lingkungan yang ekstrem dan sensor node harus dapat beroperasi secara otomatis tanpa campur tangan manusia, jaringan ini menjadi rentan akan beberapa ancaman jaringan dan dapat mempengaruhi performa dari jaringannya. Terdapat berbagai macam jenis serangan yang dapat membahayakan jaringan wireless sensor network diantaranya yang paling umum adalah sybil attack dan hello flood attack.

Dalam penelitian ini, penulis meneliti performa WSN saat diserang oleh Sybil attack dan hello flood attack dengan cara mengukur throughput, PDR(packet delivery ratio), jitter dan delay dalam jaringan WSN. Penelitian ini juga menganalisa jumlah node yang bervariasi dari 10 node sampai 30 node dengan waktu simulasi dari 10 detik sampai 30 detik lalu dianalisa jaringan ketika jaringan normal dan diserang oleh node penyerang yang bervariasi dari 1 sampai 3 penyerang. Dengan melakukan analisa tersebut, diperoleh data berupa perbandingan dampak serangan dari Sybil attack dan hello flood attack. Dampak dari sybil attack lebih berpengaruh pada parameter throughput dan pdr yang mengalami penurunan nilai hingga $69,9 \%$ untuk pdr dan $56,4 \%$ untuk throughput. Sedangkan dampak dari hello flood attack lebih berpengaruh pada parameter delay dan jitter yang mengalami kenaikan dari nilai semula 0,05 detik menjadi 0,576 detik untuk delay dan 0,579 detik untuk jitter.
\end{abstract}

Kata kunci: WSN, ad-hoc, serangan dalam WSN, Sybil, hello flood, 


\begin{abstract}
The development of science in the field of network technology occurs very quickly because it follows the development of human needs. One of the network technology that is currently attracting public attention is wireless sensor network technology (WSN). WSN is a network of connected sensors using ad-hoc wireless technology and each node sensor are used to process data collection and connect with other nodes over a wireless network. Because in most cases WSN applications are used in extreme environments and node sensors must operate automatically without human intervention, these networks become vulnerable to some network threats and may affect the performance of their networks. There are various types of attacks that can harm wireless sensor network network among the most common is sybil attack and hello flood attack.

In this study, authors examined the performance of WSN when attacked by Sybil attack and hello flood attack by measuring throughput, PDR (packet delivery ratio), jitter and delay in WSN network. This study also analyzed the number of nodes that varied from 10 nodes to 30 nodes with simulated time from 10 seconds to 30 seconds and then analyzed the network when the network was normal and attacked by the attacking nodes that varied from 1 to 3 attackers. By doing the analysis, the data can be obtained in the form of comparison of the impact of attacks from Sybil attack and hello flood attack. The impact from the sybil attack is more influential on the parameters of throughput and pdr which has decreased the maximum value up to $69.9 \%$ for $p \overline{d r}$ and $56.4 \%$ for throughput. While the impact from hello flood attack is more influential on the delay and jitter parameters that increased from the original value of 0.05 seconds to 0.576 seconds for delay and 0.579 seconds for jitter.
\end{abstract}

Keywords: WSN, ad-hoc, attacks in WSN, Sybil, hello flood, 


\section{LEMBAR PERSEMBAHAN}

Pada halaman ini izinkanlah penulis mempersembahkan tugas akhir ini dan rasa terima kasih sebesar-besarnya kepada kedua orang tua penulis, kepada Almarhum Bapak Hery Purnama. dan Ibu Sri Pusporini yang tiada hentinya mencurahkan kasih sayang dan tanpa lelah mendidik penulis sepanjang hidup penulis. Semoga Allah Subhanahu wa Ta'ala selalu mencurahkan kasih sayangNya kepada mereka, karena tak akan pernah mampu penulis membalas jasa-jasa mereka. Juga rasa terima kasih kepada diri penulis sendiri yang selalu berjuang demi tercapainya cita-cita sehingga dapat menyelesaikan tugas akhir ini.

Rasa terima kasih sebesar-besarnya juga penulis sampaikan kepada:

1. Bapak Yuda Munarko, S.Kom., M.Sc. selaku ketua jurusan Teknik Informatika Universitas Muhammadiyah Malang juga sebagai dosen yang mengajarkan penulis banyak ilmu bermanfaat selama masa studi di UMM.

2. Ibu Diah Risqiwati, M.T dan Bapak Denar Regata A. M.Kom. selaku dosen pembimbing yang tak pernah lelah dan selalu membimbing penulis sejak awal penulisan tugas akhir ini. Semoga Allah Subhanahu wa Ta'ala membalas seluruh jasa bapak selama ini. Amin.

3. Seluruh pengajar di Teknik Informatika UMM yang telah mengajarkan ilmu kepada penulis dan tak akan pernah dapat dibalas oleh penulis. Bapak dan ibu dosen lah yang telah menempa diri penulis sehingga menjadi sekarang. Semoga Allah Subhanahu wa Ta'ala juga membalas seluruh jasa bapak dan ibu. Amin.

4. Seluruh teman-teman, kerabat, dan sahabat penulis yang tak mungkin disebutkan seluruhnya. 


\section{KATA PENGANTAR}

Alhamdulillahirabbil'alamin, segala puji bagi Allah Subhanahu wa Ta'ala, atas segala limpahan rahmat, hidayah dan karuniaNya sehingga penulis mampu menyelesaikan tugas akhir ini sebagai salah satu syarat menyelesaikan studi sarjana strata 1 di Teknik Informatika Universitas Muhammadiyah Malang. Salam dan shalawat kepada Rasulullah Muhammad Shallallahu 'Alaihi Wasallam, beserta para keluarga, sahabat dan para pengikutnya hingga hari Akhir. Semoga pula segala hal yang penulis lakukan berkaitan dengan skripsi ini juga bernilai ibadah di sisi Allah Subhanahu wa Ta'ala. Amin.

Segenap kemampuan penulis telah dicurahkan dalam penyusunan tugas akhir ini. Namun demikian, penulis sangat menyadari bahwa kesempurnaan hanya milik Allah SWT. Sebagai makhluk ciptaannya tentulah diri penulis memiliki banyak keterbatasan. Oleh karena itu, segala bentuk saran dan kritik konstruktif senantiasa penulis harapkan agar di kemudian hari tulisan ini menjadi lebih baik. Di akhir kata, penulis sangat berharap tulisan ini dapat bermanfaat di hari kemudian bagi ilmu pengetahuan ataupun mampu meski hanya sekadar menambah wawasan bagi siapa pun yang membaca tulisan ini.
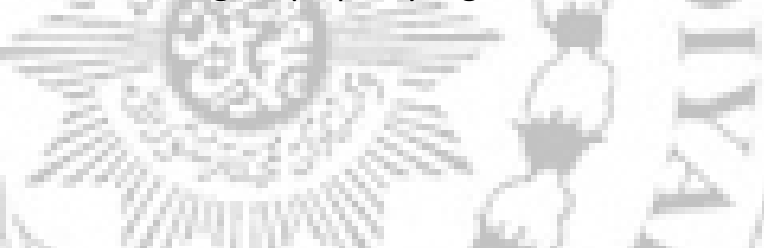

Malang, 17 Oktober 2017

Penulis 


\section{DAFTAR ISI}

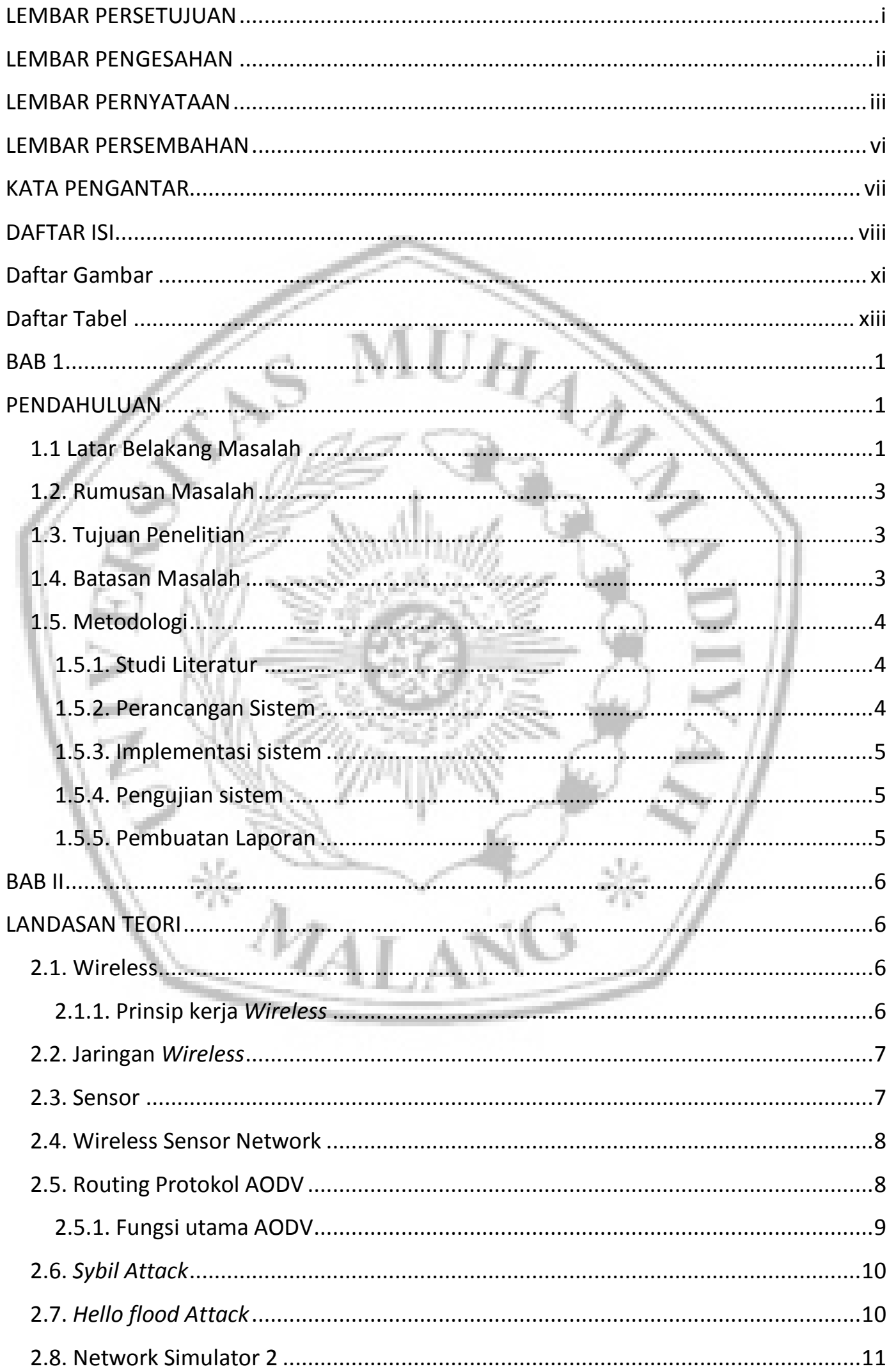




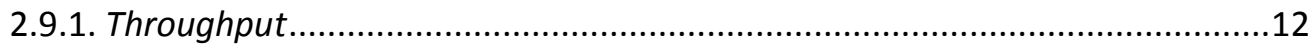

2.9.2. Packet Delivery Ratio.............................................................13

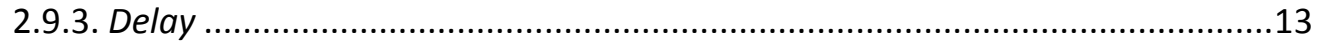

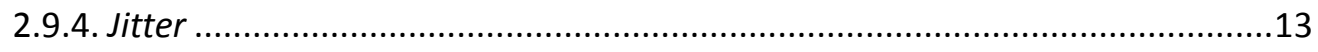

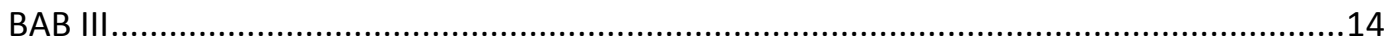

RANCANGAN SISTEM ........................................................................ 14

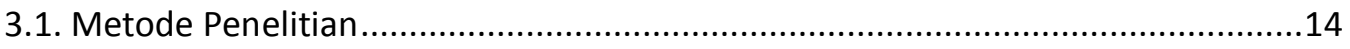

3.1.1. Perancangan Sistem ........................................................................ 14

3.1.2. Perancangan Diagram Simulasi ..........................................................14

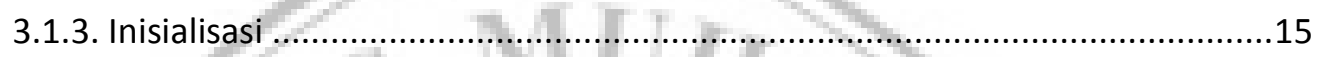

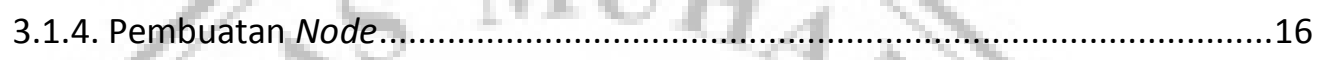

3.1.5. Membuat Pergerakan Node .........................................................17

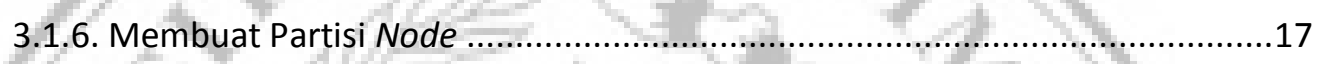

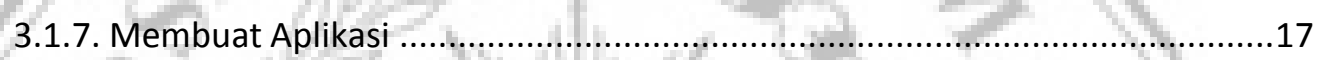

3.1.8. Membuat Node Penyerang ...................................................................17

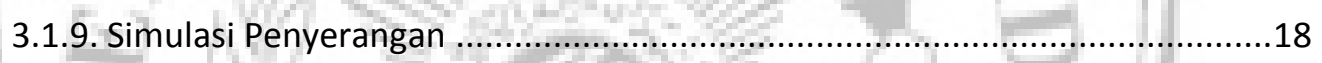

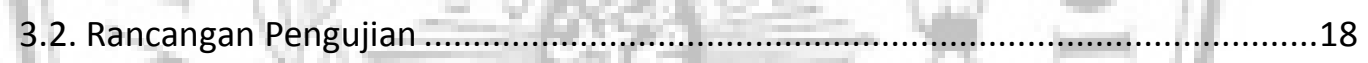

3.2.1. Skenario Pengujian Serangan Sybil Attack...............................................19

3.2.2. Skenario Pengujian Serangan Hello flood Attack ..........................................20

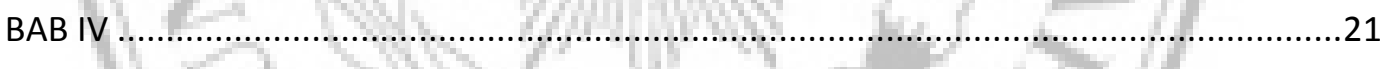

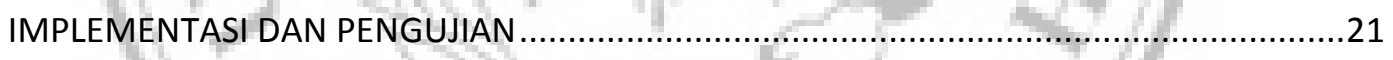

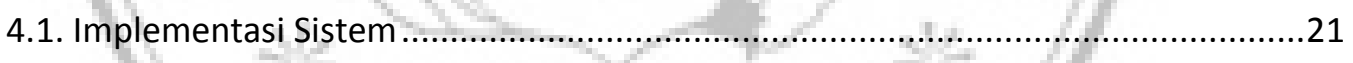

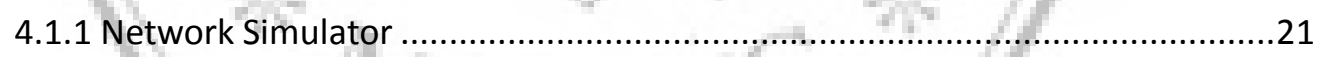

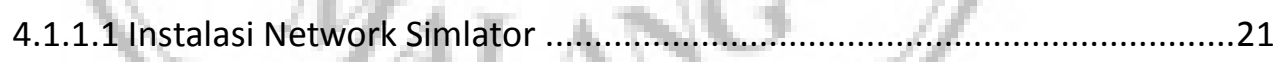

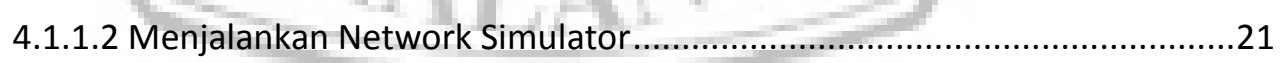

4.1.2 Network Simulator Generator .........................................................22

4.1.2.1 Menjalankan Network Simulator Generator ..................................22

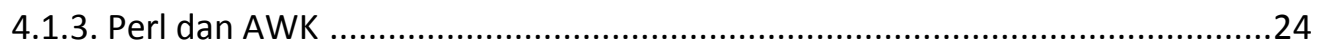

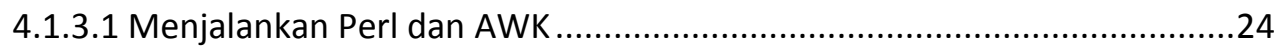

4.2. Konfigurasi Network Simulator ...........................................................24

4.2.1. Menetapkan Parameter Utama Sistem ...........................................24

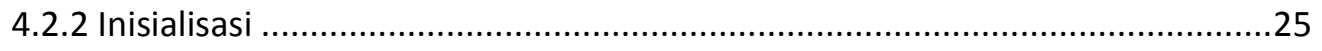

4.2.3 Membuat Node dalam Jaringan ......................................................26 
4.2.5 Menandai Node ............................................................................27

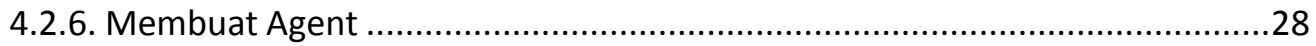

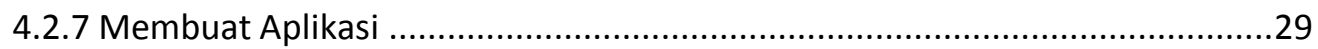

4.2.8 Menetapkan Node sebagai Penyerang ....................................................30

4.2.9 Simulasi Serangan Sybil Attack ..........................................................30

4.2.10 Simulasi Serangan Hello flood Attack .................................................32

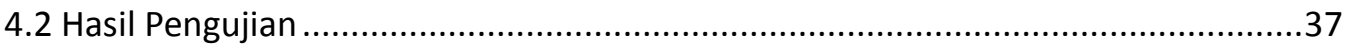

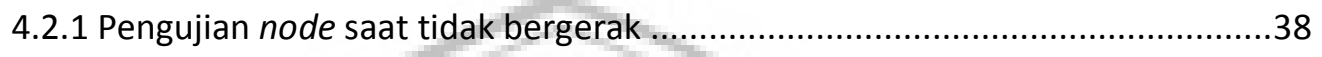

4.2.1.1 Node tidak bergerak dengan waktu $=10$ detik .................................38

4.2.1.2 Node tidak bergerak dengan waktu $=20$ detik ................................40

4.2.1.3 Node tidak bergerak dengan waktu $=30$ detik ...................................43

4.2.2 Pengujian saat node bergerak ......................................................46

4.2.2.1 Node bergerak secara random dengan waktu $=10$ detik ......................46

4.2.2.2 Node bergerak secara random dengan waktu $=20$ detik .....................49

4.2.2.3 Node bergerak secara random dengan waktu $=30$ detik ........................52

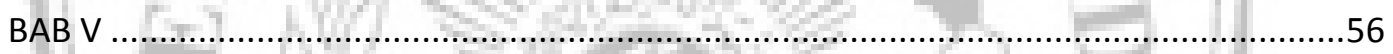

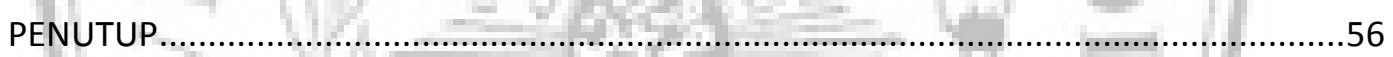

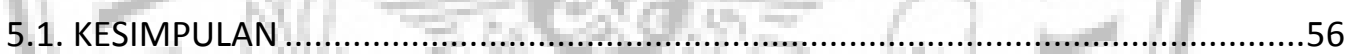

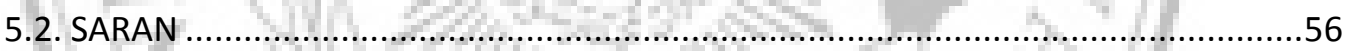

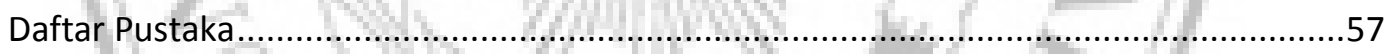




\section{Daftar Gambar}

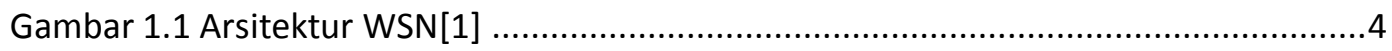

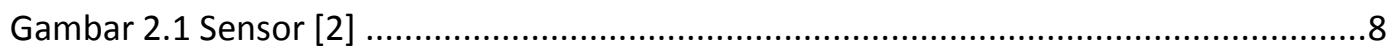

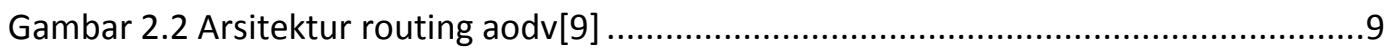

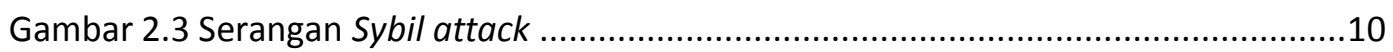

Gambar 2.4a : serangan Hello flood Attack oleh 2 node penyerang .................................11

Gambar 2.4b : serangan Hello flood Attack oleh 2 node penyerang .................................11

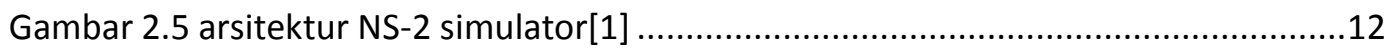

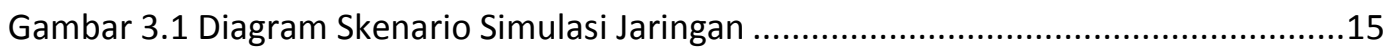

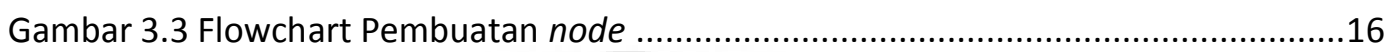

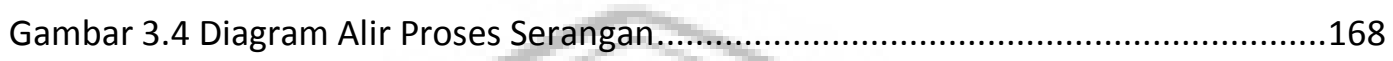

Gambar 3.5 contoh Sybil Attack ..........................................................................19

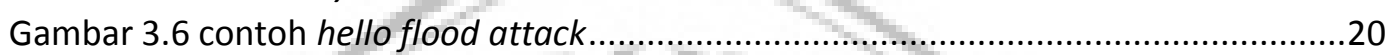

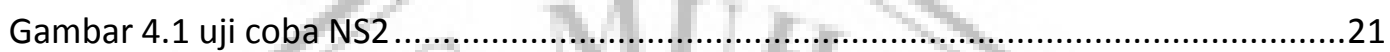

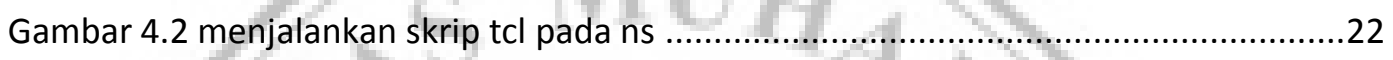

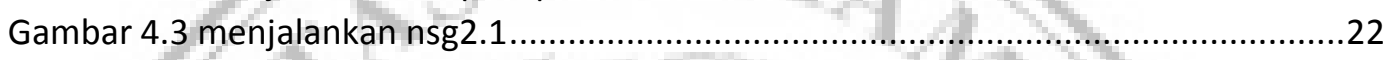

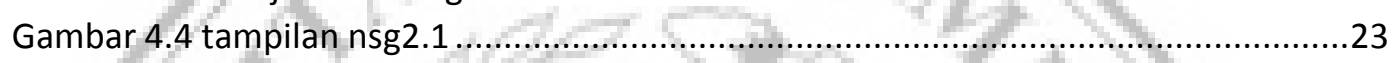

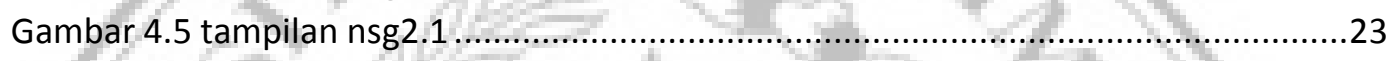

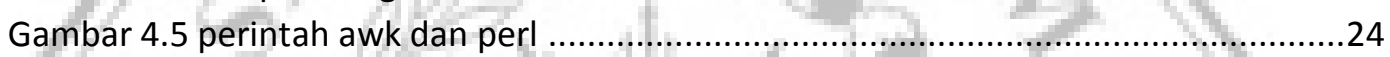

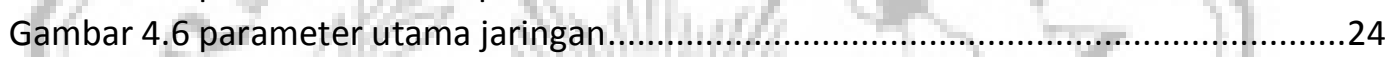

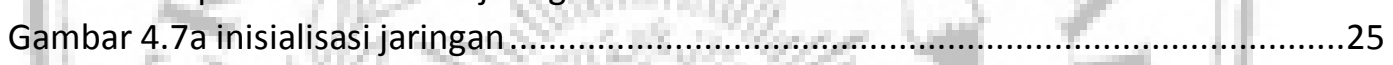

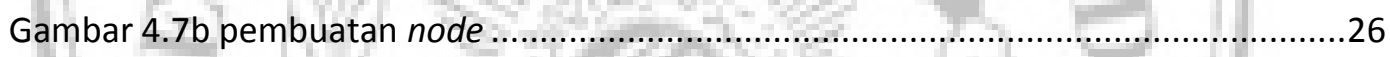

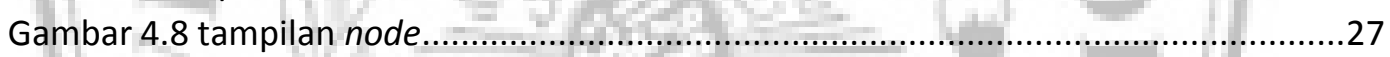

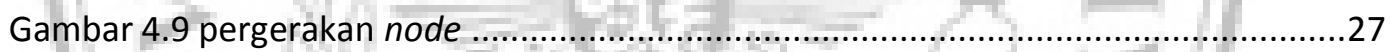

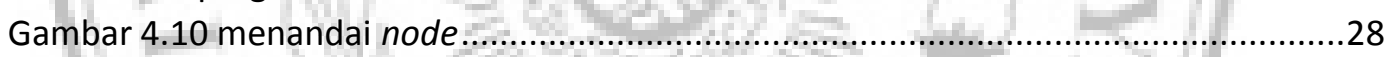

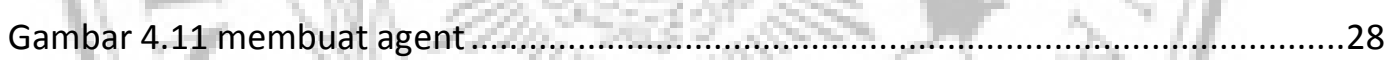

Gambar 4.12 membuat aplikasi .......................................................................29

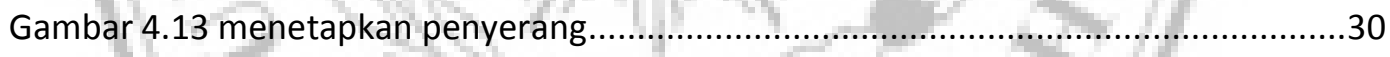

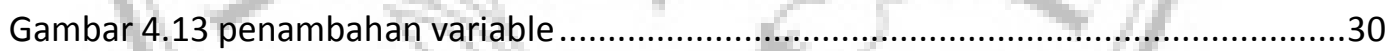

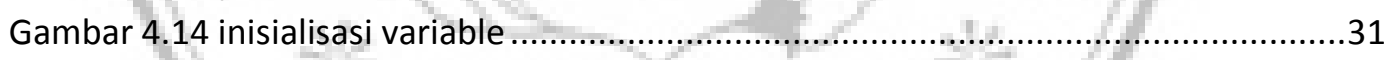

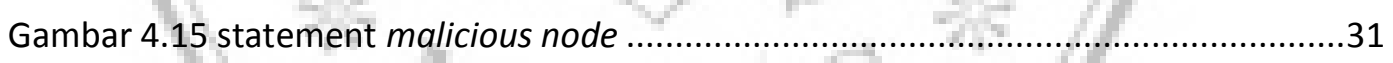

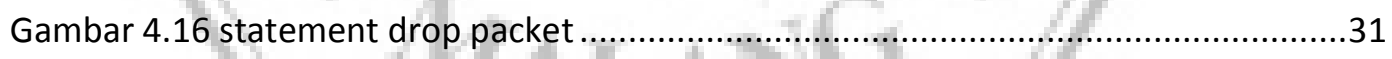

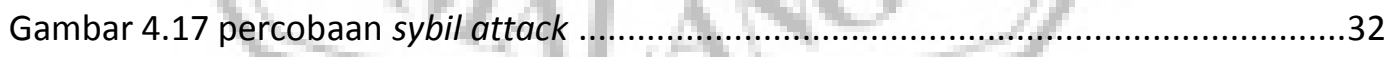

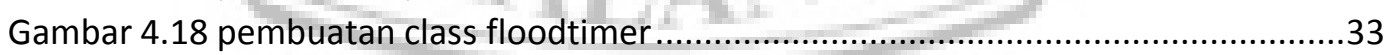

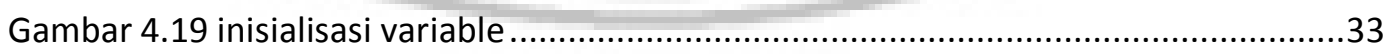

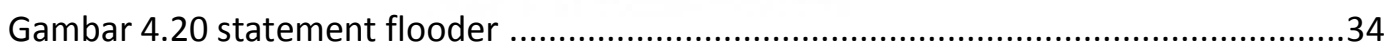

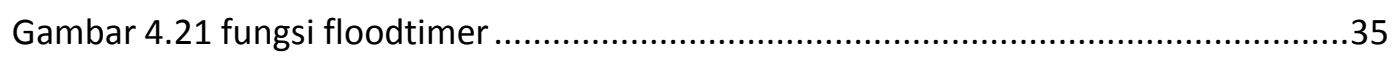

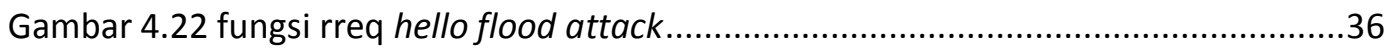

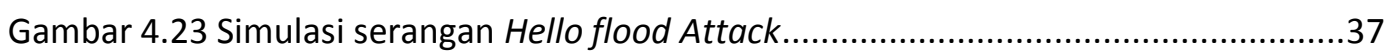

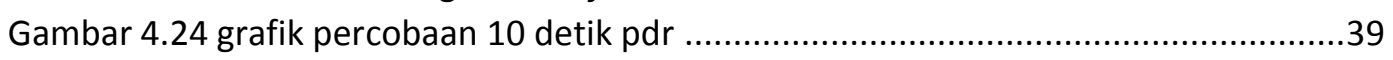

Gambar 4.25 grafik percobaan 10 detik Throughput ....................................................39

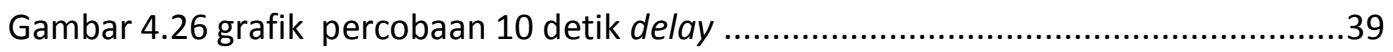

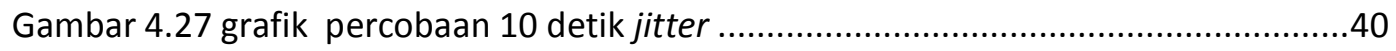

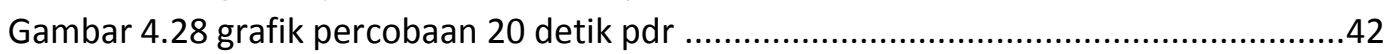

Gambar 4.29 grafik percobaan 20 detik throughput ...................................................42 


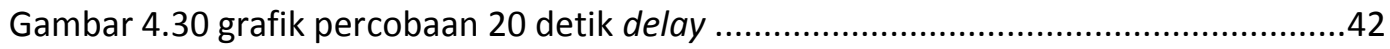

Gambar 4.31 grafik percobaan 20 detik jitter .......................................................43

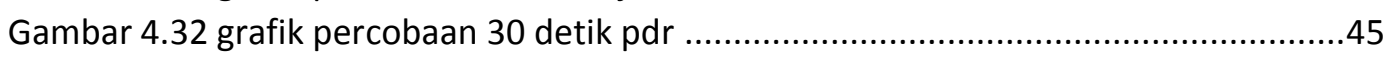

Gambar 4.33 grafik percobaan 30 detik throughput..................................................45

Gambar 4.34 grafik percobaan 30 detik delay .........................................................45

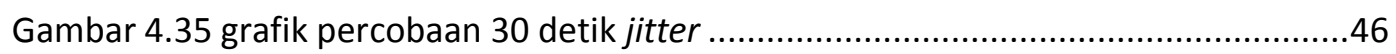

Gambar 4.36 grafik percobaan 10 detik pdr..........................................................48

Gambar 4.37 grafik percobaan 10 detik throughput ......................................................48

Gambar 4.38 grafik percobaan 10 detik delay ............................................................48

Gambar 4.39 grafik percobaan 10 detik Jitter .........................................................49

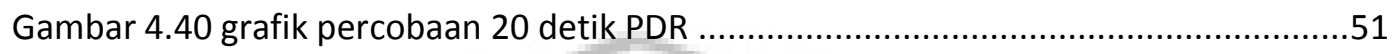

Gambar 4.41 grafik percobaan 20 detik throughput..................................................51

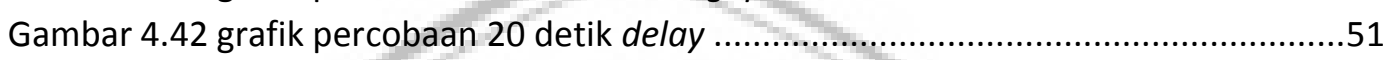

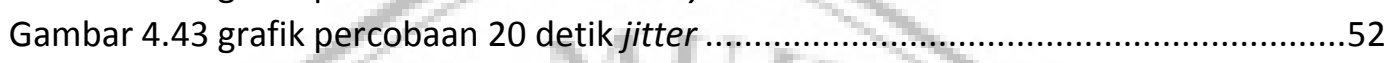

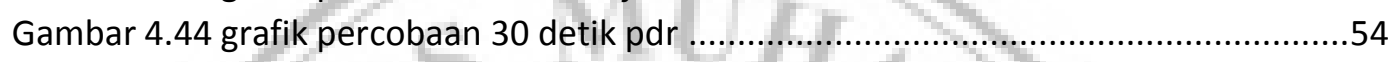

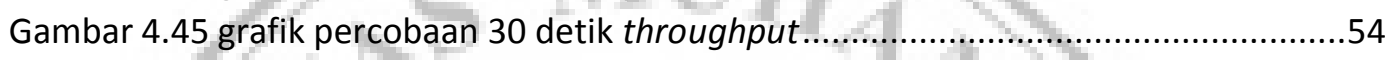

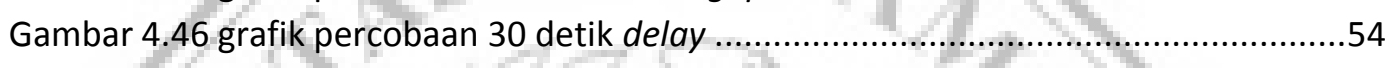

Gambar 4.47 grafik percobaan 30 detik jitter ...........................................................5

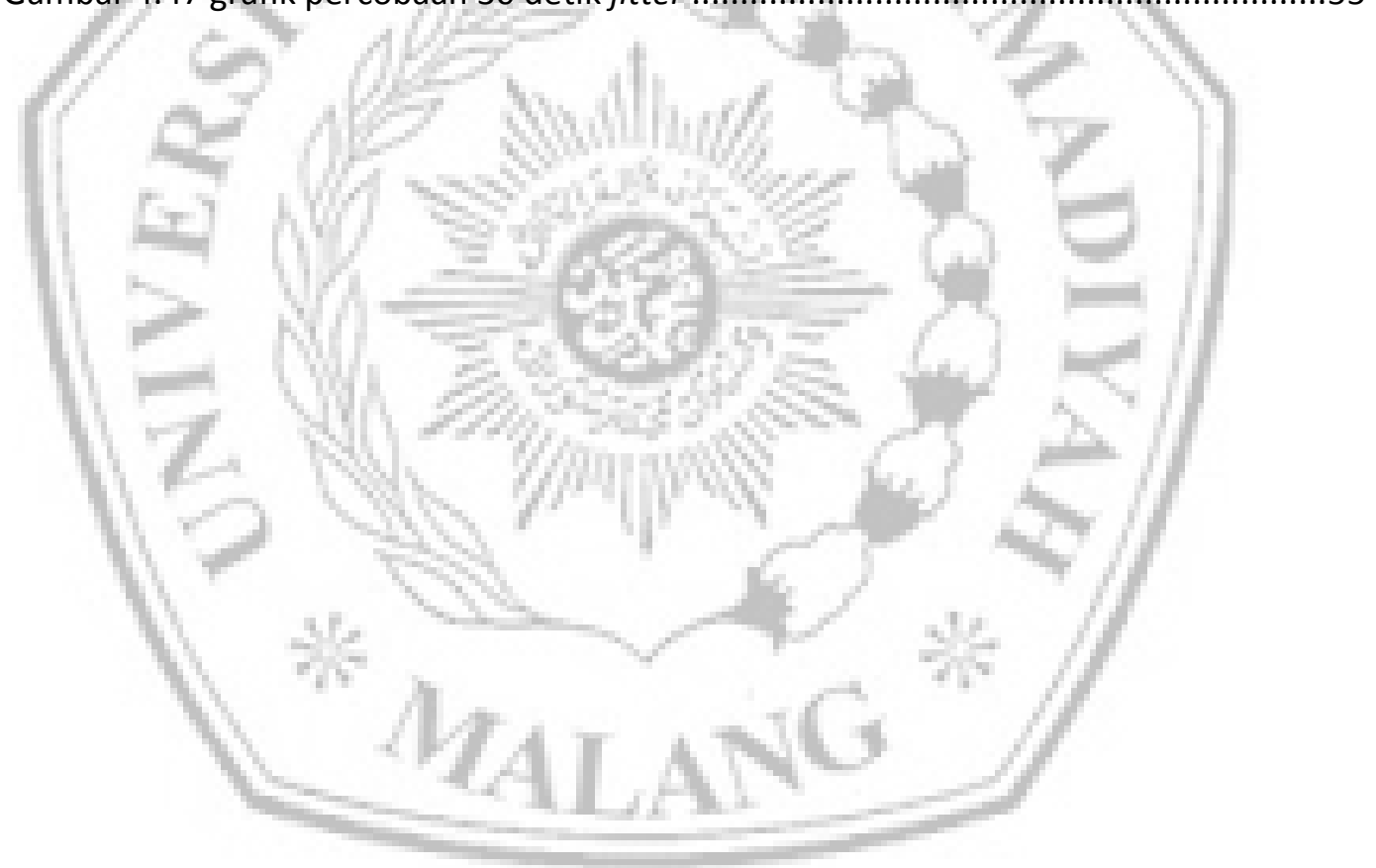




\section{Daftar Tabel}

Tabel 1.1 Parameter Sistem

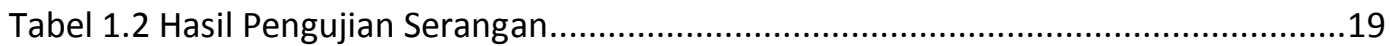

Tabel 1.3 Hasil pengujian node tidak bergerak dalam waktu 10 detik ...........................38

Tabel 1.4 hasil pengujian node tidak bergerak dalam waktu 20 detik..............................41

Tabel 1.5 hasil pengujian node tidak bergerak dalam waktu 30 detik............................44

Tabel 1.6 hasil pengujian node bergerak dalam waktu 10 detik ...................................47

Tabel 1.7 hasil pengujian node bergerak dalam waktu 20 detik .....................................50

Tabel 1.8 hasil pengujian node bergerak dalam waktu 30 detik ...................................53

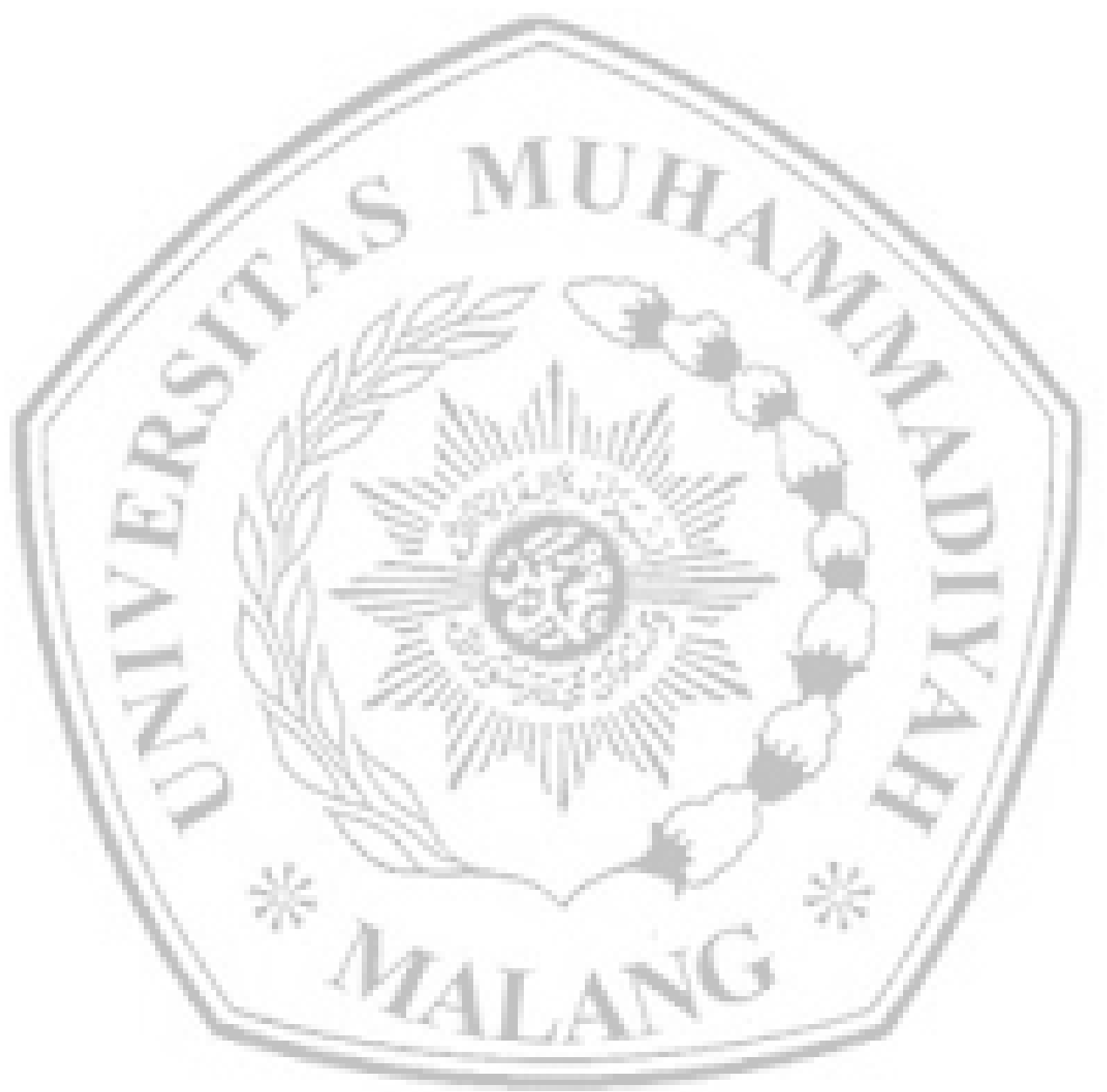




\section{Daftar Pustaka}

[1] A. Sher, "Simulation of Attacks in a Wireless Sensor Network using NS2," pp. 1-44, 2015.

[2] I. P. A. Eka Pratama and S. Suakanto, "Wireless Sensor Network," p. 603, 2015.

[3] J. Newsome, E. Shi, D. Song, and A. Perrig, "The sybil attack in sensor networks: analysis \& defenses," Proc. third Int. Symp. Inf. Process. Sens. networks IPSN04, pp. 259-268, 2004.

[4] V. P. Singh, S. Jain, and J. Singhai, "Hello Flood Attack and its Countermeasures in Wireless Sensor Networks," Int. J. Comput. Sci., vol. 7, no. 3, pp. 23-27, 2010.

[5] J. Satiti, I. D. Irawati, L. V. Yovita, F. T. Elektro, and U. Telkom, “Analisis Perbandingan Performansi Protokol Routing Aodv Dan Dsdv Pada Wireless Sensor Network Comparative Analysis of Aodv and Dsdv Routing Protocols Performance on Wireless Sensor Network," vol. 2, no. 2, pp. 1-6, 2015.

[6] A. Engels, M. Neunerdt, R. Mathar, and H. M. Abdullah, "Acceptance as a success factor for planning wireless network infrastructure," Proc. Int. Symp. Wirel. Commun. Syst., pp. 889-893, 2011.

[7] M. R. Arief, "Teknologi Jaringan Tanpa Kabel ( Wireless )," vol. 2007, no. November, pp. 1-8, 2007.

[8] P. Samundiswary and P. Dananjayan, "Performance Analysis of Trust Based AODV for Wireless Sensor Networks," Int. J. Comput. Appl., vol. 4, no. 12, pp. 6-13, 2010.

[9] V. Mehta and N. Gupta, "Performance Analysis of QoS Parameters for Wimax Networks," Int. J. Eng. Innov. Technol., vol. 1, no. 5, pp. 105-110, 2012.

[10] P. E. Pratiwi, A. F. Isnawati, A. Hikmaturokhman, A. Sandhy, and P. Purwokerto, "ANALISIS QOS PADA JARINGAN MULTI PROTOCOL LABEL SWITCHING ( MPLS ) STUDI KASUS DI PELABUHAN INDONESIA III," J. INFOTEL, vol. 6, no. 1, pp. 1-10, 2014. 